\title{
The concept of obtaining backfilling material using the dredging method
}

\author{
Maciej Gruszczyński \& Stanisław Czaban \\ Institute of Environmental Engineering, Wroclaw University of Environmental and Life Sciences, Poland \\ Szymon Zieliński \\ KGHM Polska Miedź S. A., Hydrotechnical Unit, Poland
}

\begin{abstract}
SUMMARY: One of the problems of the mining industry is the management of fine mineral tailings (with a solid phase diameter of less than $0.1 \mathrm{~mm}$ ), which are the result of the enrichment process. Due to their physical properties, mainly thickening and compressibility, the fine-grained materials are not suitable for use in large quantities in the mining industry or other industrial branches. A number of experiments were conducted to develop a technology allowing the practical use of fine-grained post-flotation tailings as hydraulic or cemented hydraulic fill and also as a material for goaf tightening. The paper presents the results of the research conducted on obtaining condensed fine-grained tailings of copper ore flotation by the dredging method. During the experiments, the following parameters were determined: pump operation parameters, material density, linear head losses On top of this, the process of depositing material on the beach was assessed. During the research both traditional measurement methods and laser scanning techniques were used to assess the deposition of material on the beach. Experimental studies have confirmed the effectiveness of obtaining material by the dredging method that can be used in backfilling technologies or for goaf tightening.
\end{abstract}

Keywords: backfill material, paste, mature fine tailings, tailings storage facility

\section{INTRODUCTION}

In Poland, over 110 million tonnes of mining waste is generated annually. The main group of waste are by-products of non-ferrous metal ore enrichment processes from washing and cleaning minerals, and coal fly ash resulting from coal combustion (Figure 1). The management of generated waste is a major problem for the economy and the natural environment in Poland.

The subject of many studies at Polish universities and foreign scientific units was the use of generated waste (Gruszczyński, 2019, Kotarska, I. 2012, Plewa, 2006) as the main material or addition to mixtures used during: hydraulic grouting of caving areas, filling unused openingout heading, underground cemented backfill, fire prevention and fire fighting Pierzyna, and Popczyk, 2014). In the coal mining technology, hydraulic grouting with fine-grained mixture of industrial waste such as fly ashes and flotation tailing is widely used (Pierzyna, and Popczyk, 2014). Scientific work is underway to apply coal fly ashes to solidify rock debris (Plewa et al. 2008). The use of fluidized bed combustion products in hydraulic backfill is being considered (Plewa et al. 2009).

The basic filling material is sand obtained from fossil deposits or mined from deposits hydraulically. The use of waste instead of sand will reduce the impact of opencast excavations and will allow for the management of significant amounts of waste that end up in tailings stor- 


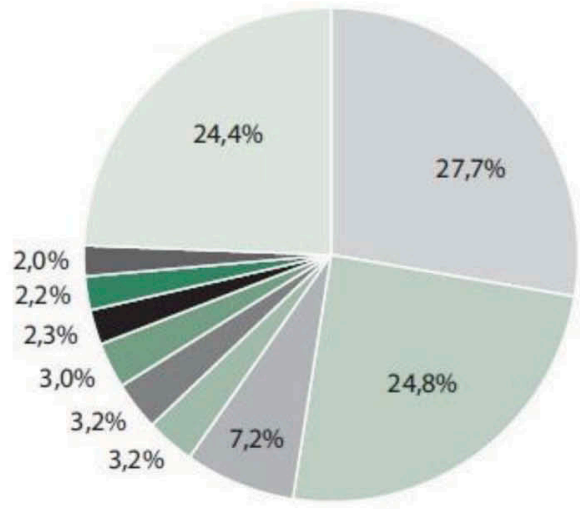

Waste from floatation dressing of non-ferrous metal ores

Waste from washing and cleaning minerals

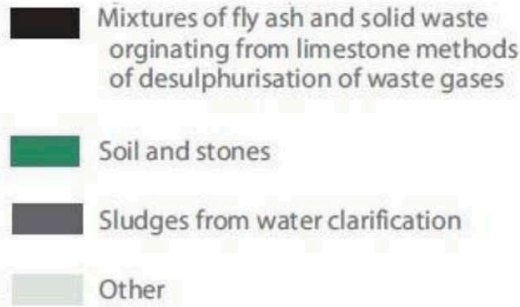

Waste from mineral non-metalliferrous excavation

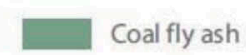

Coalfly ash

Other

Figure 1. Structure of waste generated by waste type in 2017.

Source: Bochenek, Dzik, Górksa, Kiełczykowska, Kulasza, Nowakowska, Pawłowska, Rudnicka, Sulik, Szondelmejer, Wojciechowska, and Wrzosek, 2018. Environment 2018. Spatial and Environmental Surveys Department

age Facilities (TSF). The technology of hydraulic backfill has a number of advantages such as limiting the impact of mining operations on the land surface, the possibility of operating in protective pillars, the reduction of fire, water and gas hazards and the rockburst risk reduction (Popczyk, 2014). One third of the mining tailings generated in Poland is copper ore flotation tailings, generated in KGHM Polska Miedź S.A. Ore Enrichment Plants. Despite many research works, no technology has been implemented to date by the Company for the use of tailings generated during enrichment in mining technology. Copper ore flotation tailings have for many years been the subject of research for relocation or use in industries other than mining. The use of waste as a mineral binder, proppant, sealing material for goafs or as lithification material is considered (Łuszczkiewicz, 2000, Ratajczyk 2015, Speczik et al. 2003).

\section{CHARACTERISTICS OF COPPER ORE FLOTATION TAILINGS}

At KGHM Polska Miedź S.A. extraction is carried out in three mines, ie.: Lubin, PolkowiceSieroszowice, Rudna. The Lubin Mine is the oldest of the mines operated in the enterprise and extracts red sandstone and carbonate-shale ore. The Polkowice-Sieroszowice mine extracts sandstone and shale carbonate ore, however, unlike the Lubin mine, most of the extraction is obtained from shale carbonate ore. The latest mine of the enterprise is the Rudna mine, which has the deposit with the highest mineralization from all KGHM mines. The 
Rudna Mine extracts sandstone and carbonate-shale ore (Bartlett et al. 2013). Table 1 presents the mineralogical composition of copper ore flotation tailings from individual KGHM mines.

In order to enrich the ore in the flotation process, the ore requires significant fragmentation. Figure 2 shows a typical grain size composition curve for five different enrichment processes. The particle size of tailings from copper ore flotation processes oscillates within $0.1 \mathrm{~mm}$.

At each of the three mines there are OEP. Mineral processing is adapted to the ore extracted in each of the mines. Due to this the grain size composition of the tailings differs for the individual OEP. Figure 3 presents the grain size composition curves for OEP Rudna, Polkowice and Lubin. As can be seen the thickest tailings come from OEP Lubin, while the smallest come from OEP Polkowice. Grain size indicator $d_{50}$ of tailings is in the range 20-60 $\mu \mathrm{m}$.

Flotation tailings from all three OEP flow through a pressure hydrotransport system to Tailings Storage Facility Żelazny Most (TSF ŻM) where the tailings are subjected to the process of disposal through storage. Tailings larger than $0.1 \mathrm{~mm}$ are used to build the dam body, while smaller tailings are used to seal the TSF.

\section{CHARACTERISTICS OF THE TAILINGS STORAGE FACILITY ŻELAZNY MOST}

The exploitation of TSF ŻM began in 1977 and it has been used and continuously enlarged to this day. The facility is the largest tailings pond of this type in Europe and one of the largest in the world. Figure 4 presents an aerial photograph of the object.

The facility is being built using the „upstream” method by depositing flotation tailings as a structural material for the dam body (Świdziński et al. 2015). About 10 years ago, KGHM decided to expand the existing TSF ŻM adding a Southern Quarter (SQ). The new quarter is to be adjoined to the southern part of the existing facility. The completion of the new pond is planned for 2021. The capacity of the new quarter is to be approximately $1 / 3$ of the volume of the main pond. The new quarter is to be exploited using thickened tailings technology so as to make the quality of the process water, which is pumped back from TSF to the OEP, independent from deposition area and meteorological conditions.

\section{RESEARCH ON THE POSSIBILITIES OF OBTAINING AND RELOCATION OF FINE TAILINGS.}

In TSF ŻM in which non-thickened tailings technology is used, fine tailings accumulate in the central part of the pond, while coarse tailings are most often used as a constructing material for the dam body and the beach (N. Dhadli et al.2012)]. The distribution of particles is caused by the occurring natural process of segregation and sedimentation. Figure 5 shows a typical

Table 1. Mineralogical composition of copper ore flotation tailings.

\begin{tabular}{lll}
\hline & \multicolumn{2}{l}{ KGHM mine/Content [\%] } \\
\cline { 2 - 3 } Mineral & Lubin, Rudna & Polkowice \\
\hline Calcite & 29.95 & 58.3 \\
Quartz & 44.46 & 6.85 \\
Dolomite & 7.70 & 7.82 \\
Kaolinite & 4.76 & 3.29 \\
Gypsum & 1.65 & 4.70 \\
Biotite & 3.30 & 1.12 \\
Feldspars & 1.35 & 0.82 \\
Clays & 8.35 & 4.78 \\
Desirable minerals & 1.10 & 1.32 \\
\hline
\end{tabular}

Source: Kotarska, 2012. Odpady wydobywcze z górnictwa miedzi w Polsce bilans, stan zagospodarowania i aspekty środowiskowe, Cuprum, vol. 65 , no. 4 , pp. $45-64$ 


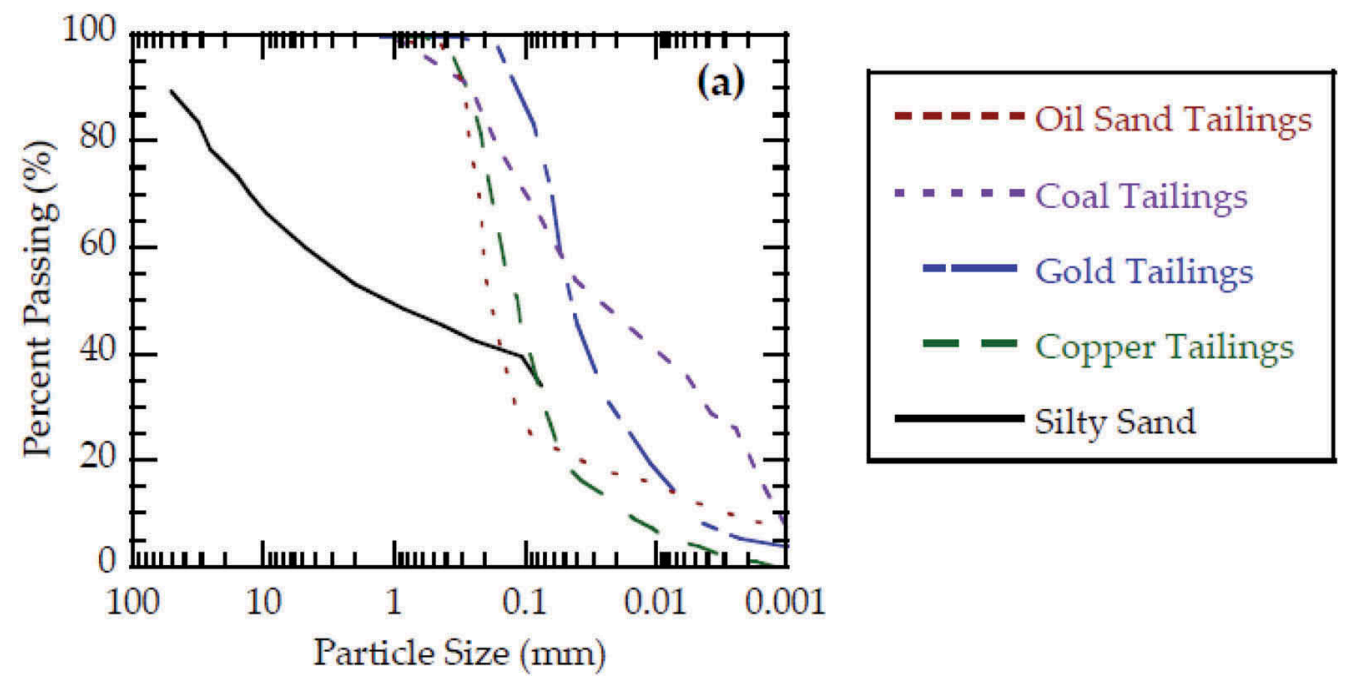

Figure 2. Grain size composition of flotation tailings after the enrichment processes: oil sand, coal, gold, silty sand.

Source: Gorakhki and Bareither. 2017. Sustainable Reuse of Mine Tailings and Waste Rock as Water-Balance Covers. Minerals, vol. 7, no. 7, p. 128

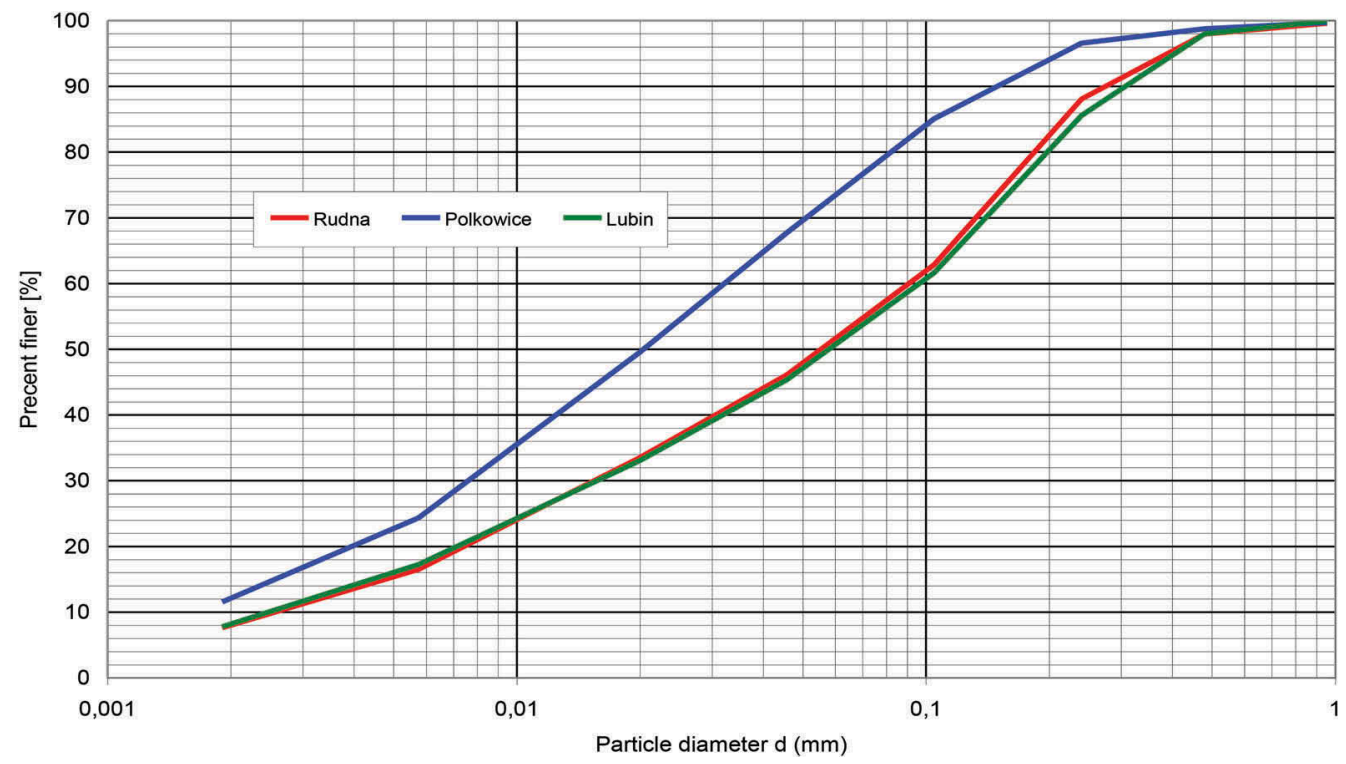

Figure 3. Average grain size compositions of tailings from OEP Rudna, Polkowice and Lubin.

Source: own study

cross-section of a TSF with marked zones of deposits of individual types of tailings. In the central part of TSF Mature Fine Tailings (MFT) deposit zone can be observed (N. Dhadli et al. 2012, Wang et al. 2014, Wells et al. 2011). MFT was the subject of the research presented in the article.

During the research conducted in 2010, the presence of MFT in TSF ŻM was detected. Considering the operating technology of the new facility, i.e. the southern quarter, it was 


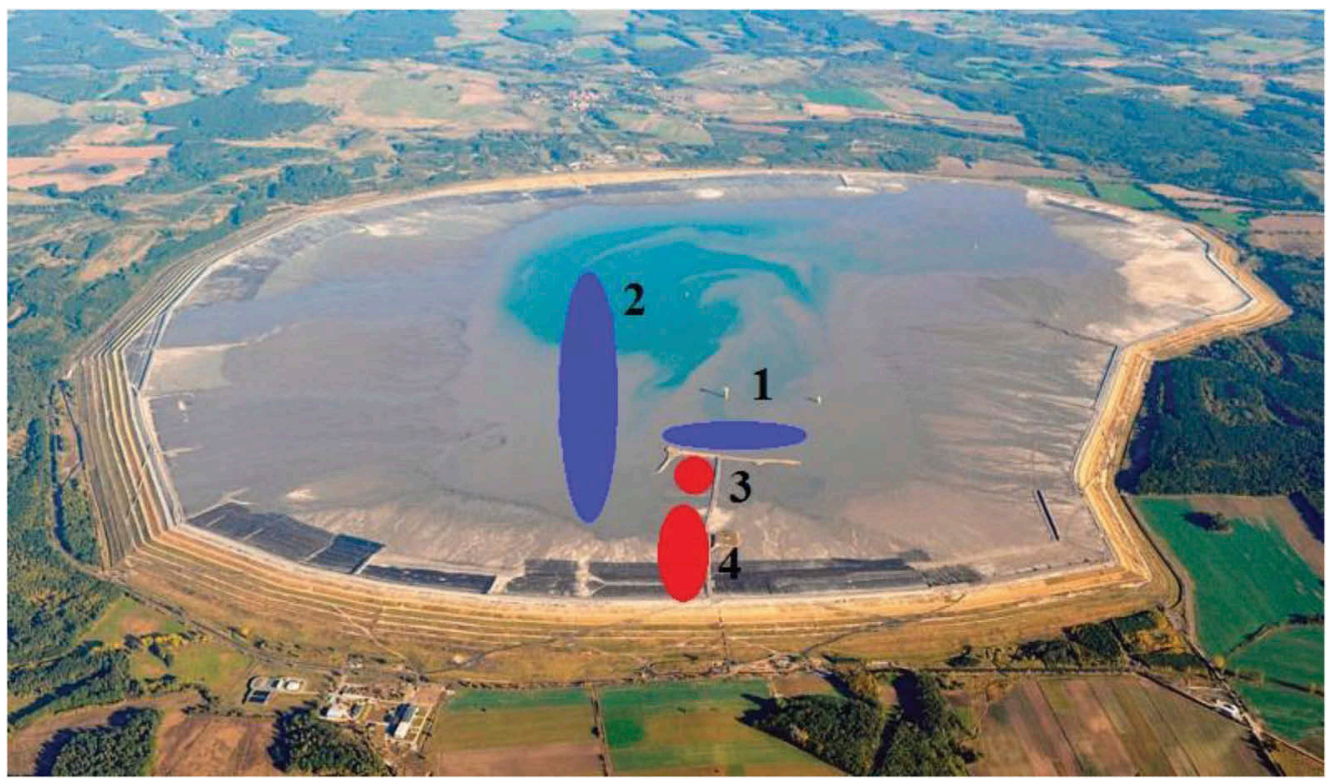

Figure 4. Tailings Storage Facility Żelazny Most seen from a bird's eye view. 1-2 regions of the dredger work. 3-4 deposition areas. Photo taken during drone flight.

Source: GeoPixel 2017. Wykonaliśmy nalot fotogrametryczny nad zbiornikiem unieszkodliwiania odpadów wydobywczych Żelazny Most - GeoPixel UAV dla geodezji. [Online] http://www.geopixel.pl/wykonalismy-nalot-foto grametryczny-nad-zbiornikiem-unieszkodliwiania-odpadow-wydobywczych-zelazny-mostl. [Accessed: 20-Jul $-2018]$.

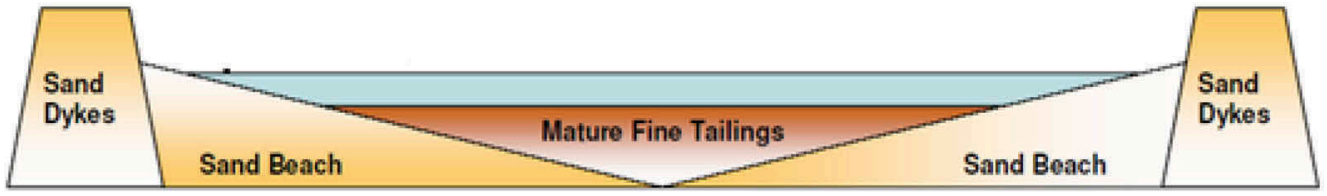

Figure 5. MFT deposition zone in cross-section of TSF.

Source: Beier, and Sego, 2008. The Oil Sands Tailings Research Facility. Geotechnical News, no. June.

proposed that MFT be used as thickened tailings transferred from the main facility ŻM to the new quarter. This solution would reduce the costs of thickening of tailings in the thickening station. The TSF ŻM would be used as a large thickener with an existing deposit. MFT collection and transport had to be resolved. The Institute of Environmental Engineering of Wroclaw University of Environmental and Life Sciences carried out the research on the dredging, transport and deposit of MFT tailings. During the research and analysis of the collected results, the concept appeared of using the acquired MFT as a material that could be used to produce a backfill paste or as a material for grouting of caving areas.

The aim of the study was to assess the behavior of the MFT deposit in the reservoir of the TSF ŻM under continuous material collection in a period of more than 24 hours. Semitechnical (field) measurements of the collecting, transporting and deposition of copper ore flotation tailings were carried out as well as measurements of geometry, volume and depositing efficiency (Figure 8) using high resolution laser scanning techniques. Both the stability of tailings inflow to the dredging pump and the dynamics of rheological parameters of pumped material were examined. The variability of concentration of dredged material as a function of time was assessed. The behavior of the slope of deposited tailings and its garin size composition were examined. During the research the Watermaster Classic IV dredger was used. Areas 
of the dredger's work during the tests and the location of the depositing areas is shown in Figure 4. The laser scanning technique was used to determine the behavior of the tailings deposited on the TSF ŻM beach. The volume of deposited tailings was determined, as well as the slope of the deposited material. Measurement methodologies were developed and measurements installation were made. The installation diagram is shown in Figure 6. During the experiments carried out on-line such parameters as flow rate, flow drag and density of dredged MFT were noted.

A sampling system from the pressure collector was designed and installed. For laboratory tests, the samples were taken from the material deposited on the plot and from the discharge pressure collector of the dredger. Samples were taken from various dredger work positions shown in Figure 7. Laboratory tests of the grain size composition of collected tailings were carried out (Figure 8). No difference in composition as a function of location was observed.

Geodetic data collected during measurements with a laser scanner was collected, and a spatial numerical model of individual stages of deposition was built. Fuel consumption during the dredger operation, position change and pressure in the discharge pipeline were also examined.

The paper presents the results of a test lasting 31 hours of continuous dredging of a MFT deposit. During the tests, the density of the transported mixture varied from 1069.9 to $1292 \mathrm{~kg} \cdot \mathrm{m}^{-3}$. The concentration by volume of the transported mixture varied from 0.0387 to 0.1618 . Table 2 gives the range of changes in volumetric flow rate of the mixture. The average hourly flow rate of the mixture was in range from 147 to $394 \mathrm{~m}^{3} \cdot \mathrm{h}^{-1}$. Solid phase volume flow rates were calculated from (1):

$$
V_{s}=c_{v} Q_{m}
$$

The solids flow rate was in range from 10.0 to $53,5 \mathrm{~m}^{3} \cdot \mathrm{h}^{-1}$. The average flow rate was $28.2 \mathrm{~m}^{3} \cdot \mathrm{h}^{-1}$. Mass flow rates of water in the mixture were calculated from (2):

$$
G_{w}=\left(1-c_{v}\right) Q_{m} \rho_{w}
$$

The water flow rate was from 124,5 to $340,5 \mathrm{Mg} \cdot \mathrm{h}^{-1}$. The average flow rate was $223.8 \mathrm{Mg} \cdot \mathrm{h}^{-1}$. Mass flow rates of solids in the mixture were calculated from (3):

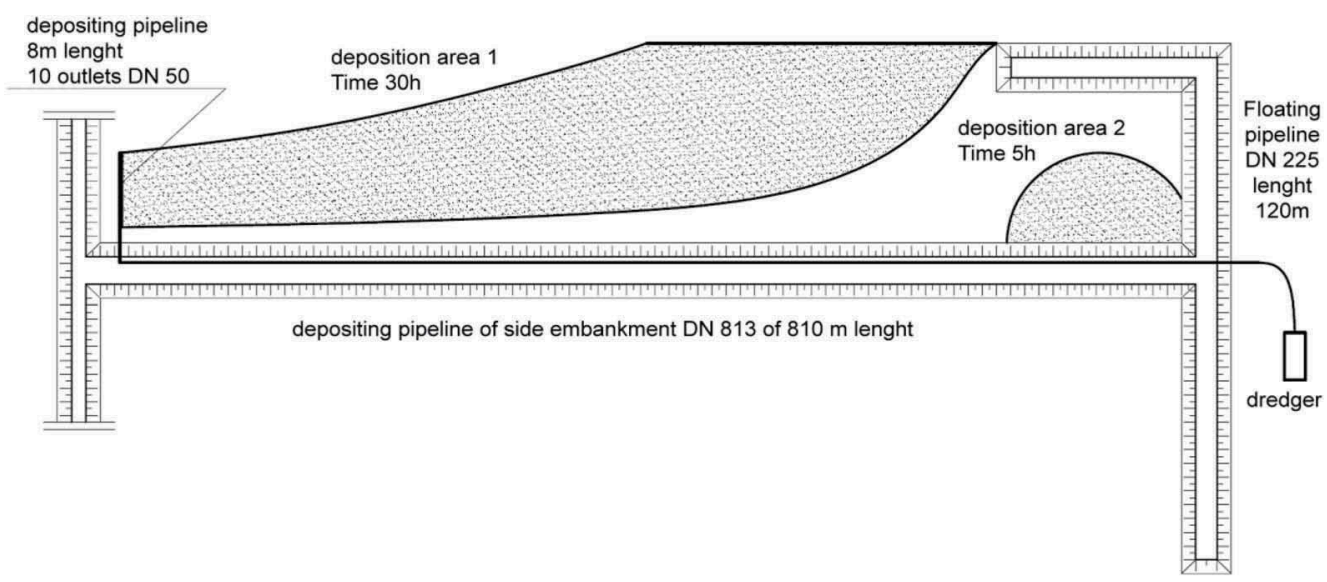

Figure 6. Scheme of transport, measuring and deposition installation of tailings.

Source: own study 


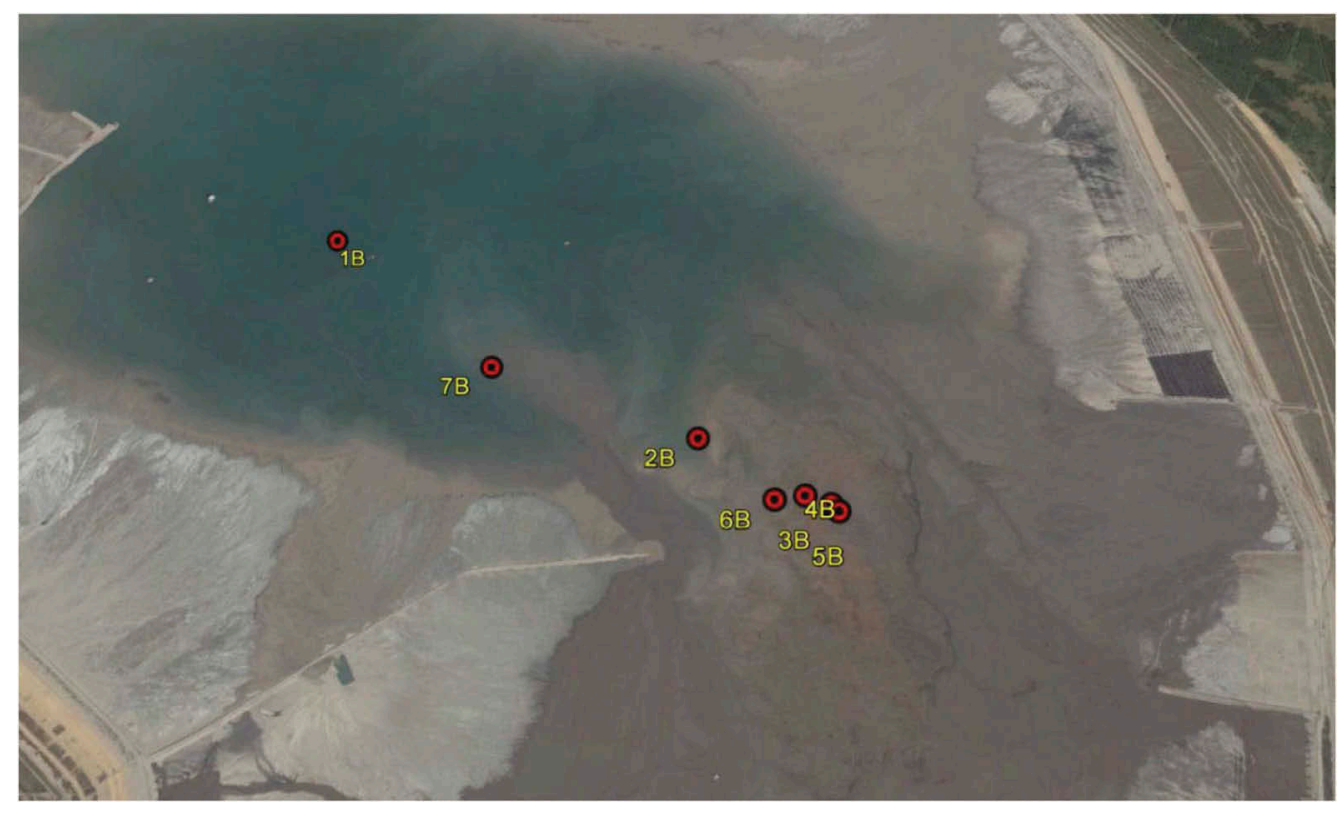

Figure 7. Location of dredger during the tailings excavating.

Source: own study (Google Earth)

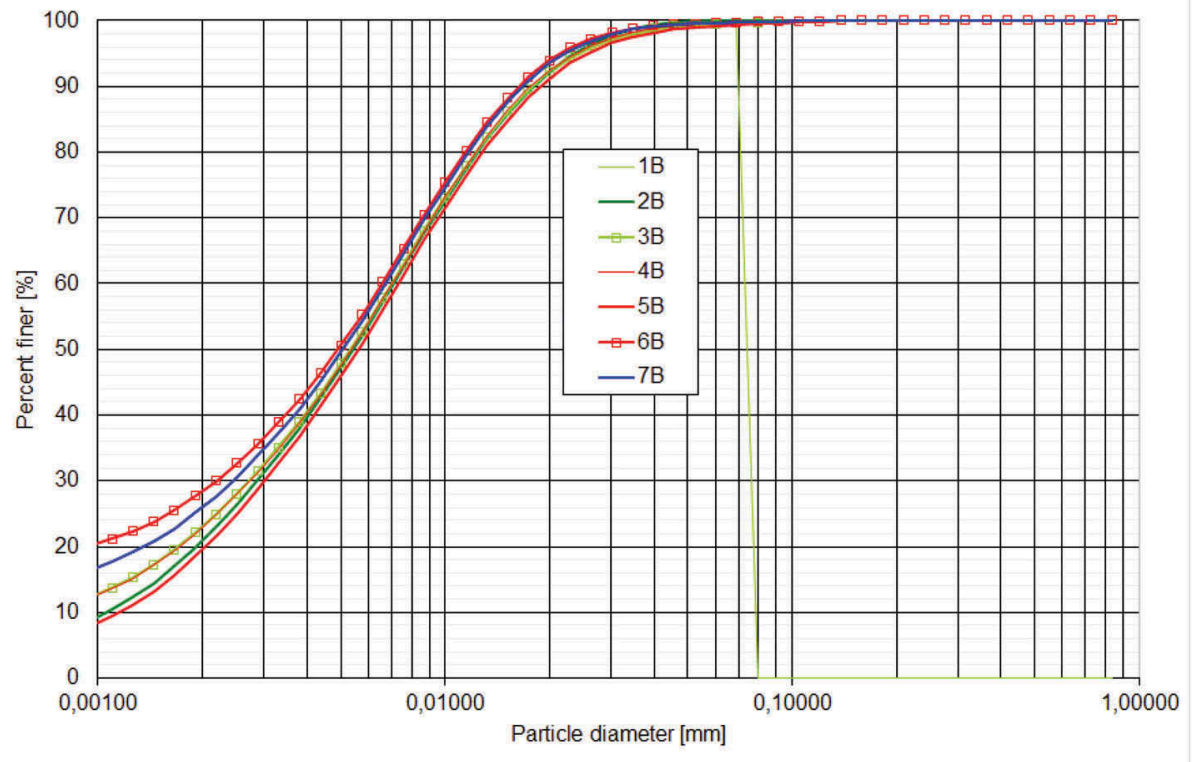

Figure 8. Grain size compositions of tailings collected in different positions of the dredger.

Source: own study 
Table 2. Parameters of the dredging vessel between 11:00 the first day and 18:00 the second day of the experiment.

\begin{tabular}{|c|c|c|c|c|c|c|c|}
\hline \multirow[b]{3}{*}{ Time } & \multirow[b]{2}{*}{ Mixture } & \multirow[b]{2}{*}{$\begin{array}{l}\text { Concentration } \\
\text { by volume }\end{array}$} & \multicolumn{5}{|l|}{ Flow rate } \\
\hline & & & Mixture & Solids & $\begin{array}{l}\text { Mass of } \\
\text { water }\end{array}$ & $\begin{array}{l}\text { Mass of } \\
\text { solids }\end{array}$ & $\begin{array}{l}\text { Mass of } \\
\text { mixture }\end{array}$ \\
\hline & $\rho_{\mathrm{m}}$ & $\mathrm{C}_{\mathrm{v}}$ & $\mathrm{Q}_{\mathrm{m}}$ & $\mathrm{V}_{\mathrm{s}}$ & $\mathrm{G}_{\mathrm{w}}$ & $\mathrm{G}_{\mathrm{s}}$ & $\mathrm{G}_{\mathrm{m}}$ \\
\hline hour & $\mathrm{kg} \cdot \mathrm{m}^{-3}$ & - & $\mathrm{m}^{3} \cdot \mathrm{h}^{-1}$ & $\mathrm{~m}^{3} \cdot \mathrm{h}^{-1}$ & $\mathrm{Mg} \cdot \mathrm{h}^{-1}$ & $\mathrm{Mg} \cdot \mathrm{h}^{-1}$ & $\mathrm{Mg} \cdot \mathrm{h}^{-1}$ \\
\hline 11 & 1245.1 & 0.1358 & 394.0 & 53.5 & 340.5 & 150.0 & 490.5 \\
\hline 12 & 1271.3 & 0.1503 & 353.5 & 53.1 & 300.4 & 149.0 & 449.4 \\
\hline 13 & 1267.7 & 0.1483 & 282.4 & 41.9 & 240.5 & 117.5 & 358.0 \\
\hline 14 & 1253.1 & 0.1403 & 261.8 & 36.7 & 225.0 & 103.0 & 328.0 \\
\hline 15 & 1292.0 & 0.1618 & 269.1 & 43.5 & 225.5 & 122.1 & 347.6 \\
\hline 16 & 1257.4 & 0.1426 & 273.8 & 39.0 & 234.7 & 109.5 & 344.2 \\
\hline 17 & 1269.4 & 0.1493 & 290.8 & 43.4 & 247.4 & 121.8 & 369.1 \\
\hline 18 & 1250.0 & 0.1386 & 326.3 & 45.2 & 281.1 & 126.8 & 407.9 \\
\hline 19 & 1220.3 & 0.1221 & 280.1 & 34.2 & 245.9 & 95.9 & 341.8 \\
\hline 20 & 1161.5 & 0.0895 & 350.3 & 31.3 & 318.9 & 87.9 & 406.9 \\
\hline 21 & 1069.9 & 0.0387 & 258.7 & 10.0 & 248.6 & 28.1 & 276.7 \\
\hline 22 & 1099.2 & 0.0550 & 230.5 & 12.7 & 217.8 & 35.6 & 253.4 \\
\hline 23 & 1111.1 & 0.0616 & 201.9 & 12.4 & 189.5 & 34.9 & 224.3 \\
\hline 0 & 1111.4 & 0.0617 & 267.8 & 16.5 & 251.3 & 46.4 & 297.7 \\
\hline 1 & 1165.8 & 0.0919 & 224.8 & 20.7 & 204.2 & 57.9 & 262.1 \\
\hline 2 & 1133.4 & 0.0739 & 303.2 & 22.4 & 280.8 & 62.9 & 343.7 \\
\hline 3 & 1196.2 & 0.1087 & 239.6 & 26.1 & 213.6 & 73.1 & 286.7 \\
\hline 4 & 1196.9 & 0.1091 & 220.9 & 24.1 & 196.8 & 67.6 & 264.4 \\
\hline 5 & 1163.7 & 0.0907 & 221.8 & 20.1 & 201.7 & 56.4 & 258.1 \\
\hline 6 & 1078.0 & 0.0433 & 237.0 & 10.3 & 226.7 & 28.7 & 255.5 \\
\hline 7 & 1140.2 & 0.0777 & 273.7 & 21.3 & 252.4 & 59.7 & 312.1 \\
\hline 8 & 1147.7 & 0.0819 & 267.5 & 21.9 & 245.6 & 61.4 & 307.0 \\
\hline 9 & 1160.5 & 0.0890 & 249.4 & 22.2 & 227.2 & 62.2 & 289.5 \\
\hline 13 & 1276.2 & 0.1531 & 147.0 & 22.5 & 124.5 & 63.1 & 187.6 \\
\hline 14 & 1266.8 & 0.1479 & 172.4 & 25.5 & 146.9 & 71.5 & 218.4 \\
\hline 15 & 1281.2 & 0.1559 & 171.8 & 26.8 & 145.0 & 75.1 & 220.1 \\
\hline 16 & 1278.6 & 0.1544 & 168.3 & 26.0 & 142.3 & 72.9 & 215.2 \\
\hline 17 & 1265.7 & 0.1473 & 180.5 & 26.6 & 153.9 & 74.5 & 228.4 \\
\hline 18 & 1264.1 & 0.1463 & 189.7 & 27.8 & 161.9 & 77.9 & 239.8 \\
\hline Minimum & 1069.9 & 0.0387 & 147.0 & 10.0 & 124.5 & 28.1 & 187.6 \\
\hline Average & 1203.3 & 0.1126 & 252.0 & 28.2 & 223.8 & 79.1 & 302.9 \\
\hline Maximum & 1292.0 & 0.1618 & 394.0 & 53.5 & 340.5 & 150.0 & 490.5 \\
\hline
\end{tabular}

Source: own study

$$
G_{s}=c_{v} Q_{m} \rho_{s}
$$

The solid phase flow rate was from 28,1 to $150 \mathrm{Mg} \cdot \mathrm{h}^{-1}$. The average solid phase flow rate during individual hours was $79.1 \mathrm{Mg} \cdot \mathrm{h}^{-1}$.

The results of the measurement using laser scanning for the depositing region number 4 from Figure 4 Czaban et al. 2017). The Figure 9 presents the raw data of the measurements taken in the field for two cases - area before and after depositing.

Based on the collected point cloud, a numerical surface model was created before and after depositing (Figure 10).

By analyzing the changes occurring on the deposition area by comparing mathematical models, the average slope of the deposited MFT surface can be determined. 

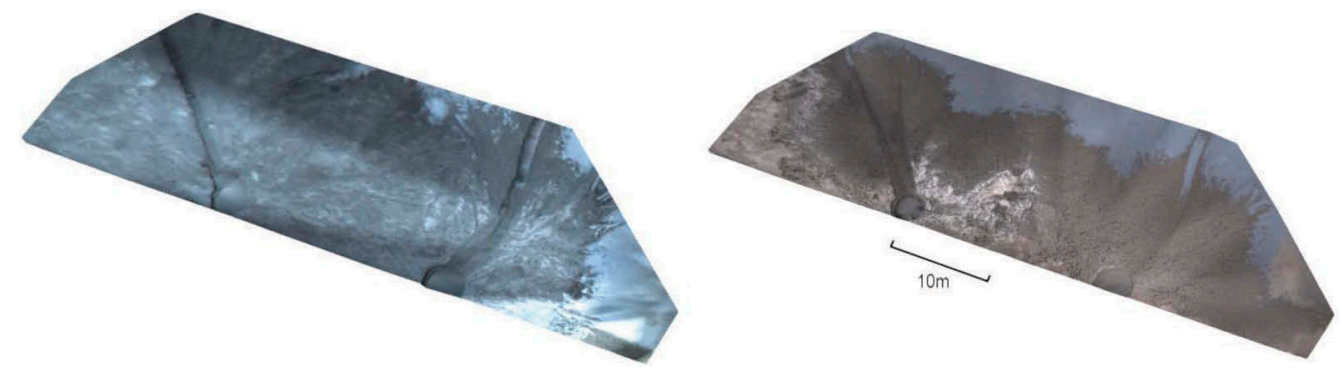

Figure 9. Point clouds of the analysis area of the tailings deposition area No. 4 for the state before depositing (state 0 ) and after deposition (state 1).

Source: own study

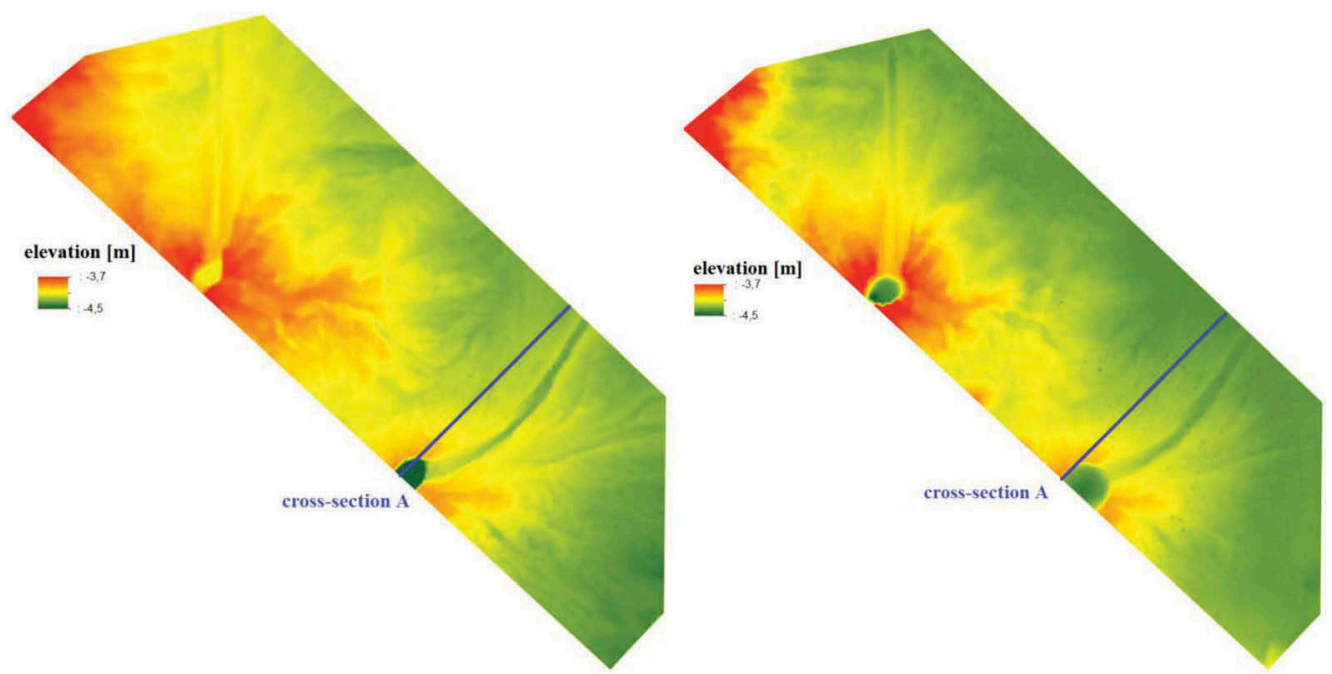

Figure 10. Triangulated Irregular Network (TIN) of research area. State before depositing (state 0) and after depositing (state 1).

Source: own study

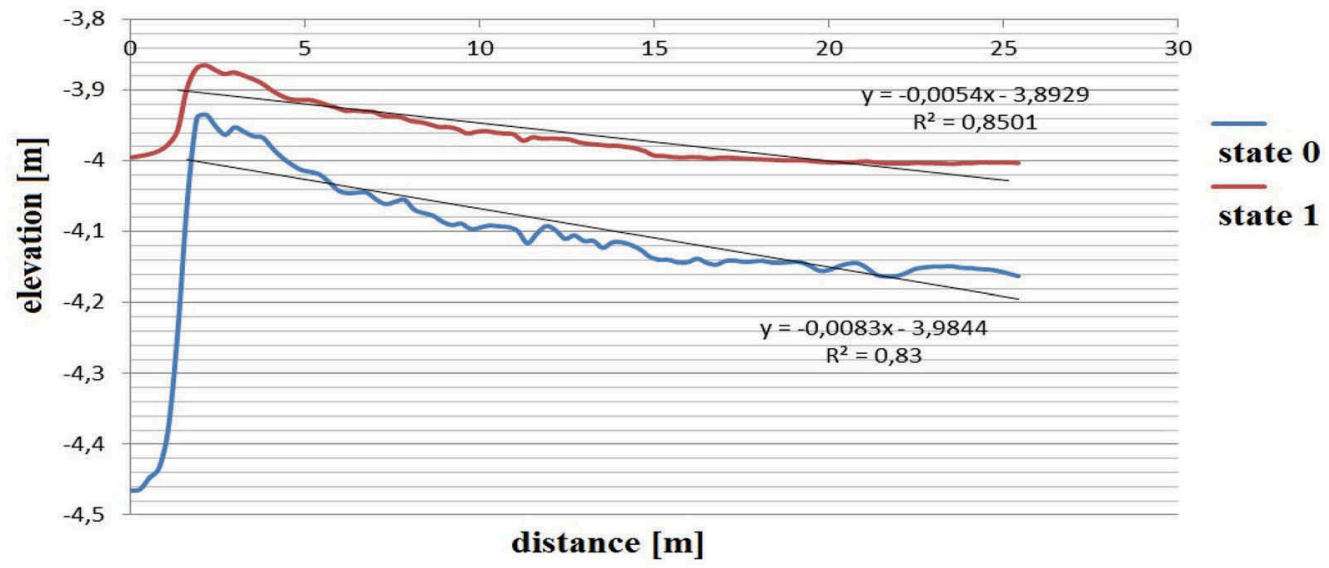

Figure 11. Cross-section A for the area of depositing tailings No. 4 - state 0 and 1.

Source: own study 


\section{RHEOLOGICAL RESEARCH OF MFT}

Rheological tests were carried out on tailings collected while dredging. Two-parameter Bingham model (4) was chosen to describe the results of rheological measurements of the collected samples:

$$
\tau=\tau_{o}+\eta_{B} \dot{\gamma}
$$

12 tailings flow curves with different concentrations were analyzed. The analyses of the dependence of individual rheological parameters of the Bingham model in relationship to concentration by solids $\mathrm{c}_{\mathrm{s}}$ were executed. The exponential equation [2][7][8], with was used to describe the relationship between concentration, yield stress (5) and viscosity (6) of Bingham model.

$$
\begin{aligned}
& \eta_{B}=a \cdot c_{s}{ }^{b} \\
& \tau_{o}=c \cdot c_{s}{ }^{d}
\end{aligned}
$$

The approximation results (7) and (8) using the method of minimizing the residual sum of squared deviations (Gruszczyński, 2019):

$$
\begin{gathered}
\eta_{B}=20,6 \cdot c_{s}^{7,83} \\
\tau_{o}=11553 \cdot c_{s}^{7,05}
\end{gathered}
$$

The fit of the model to the collected measurement data is shown in Figure 12.
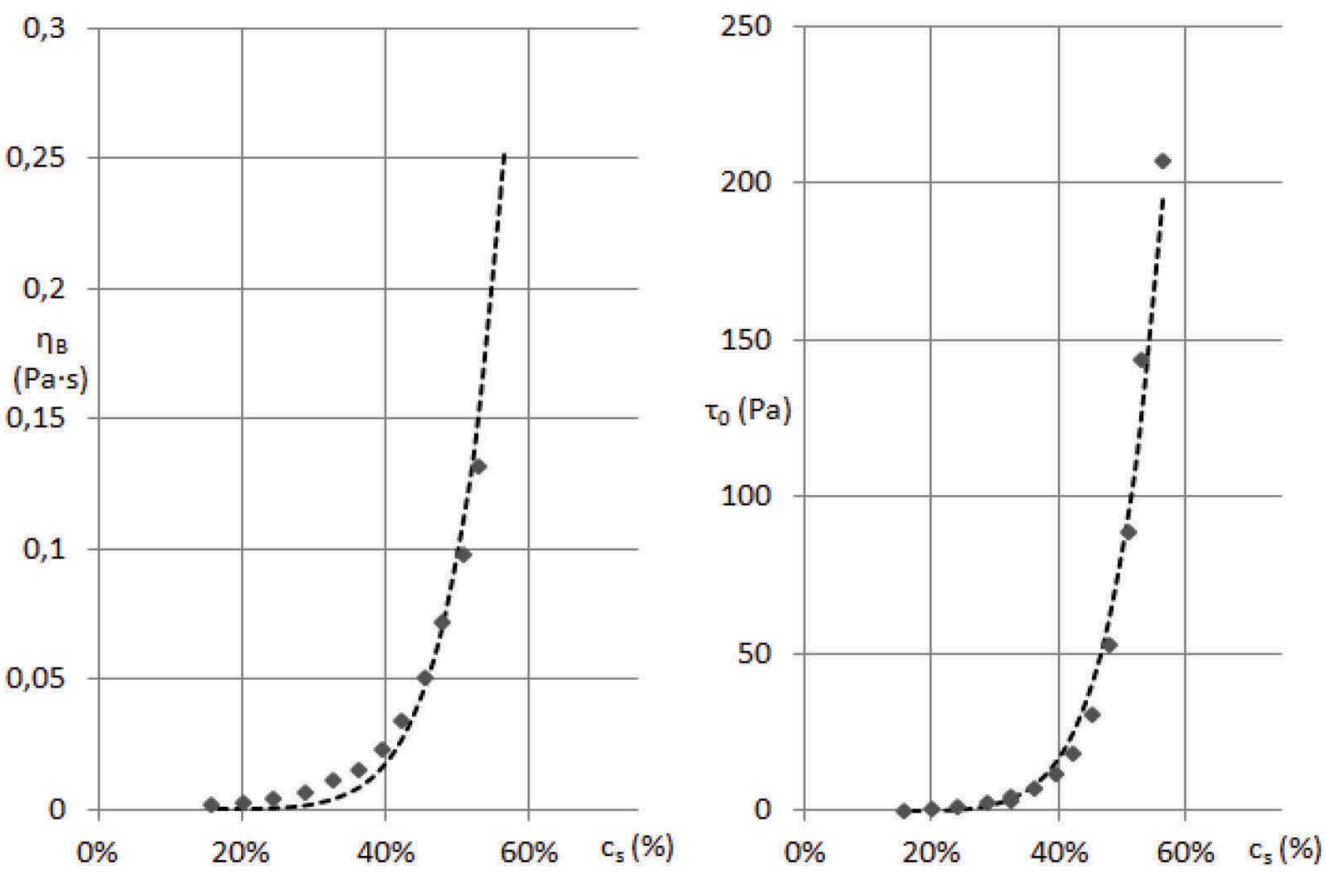

Figure 12. Shape of the yield stress model and the viscosity model with 12 measuring points. Source: own study 


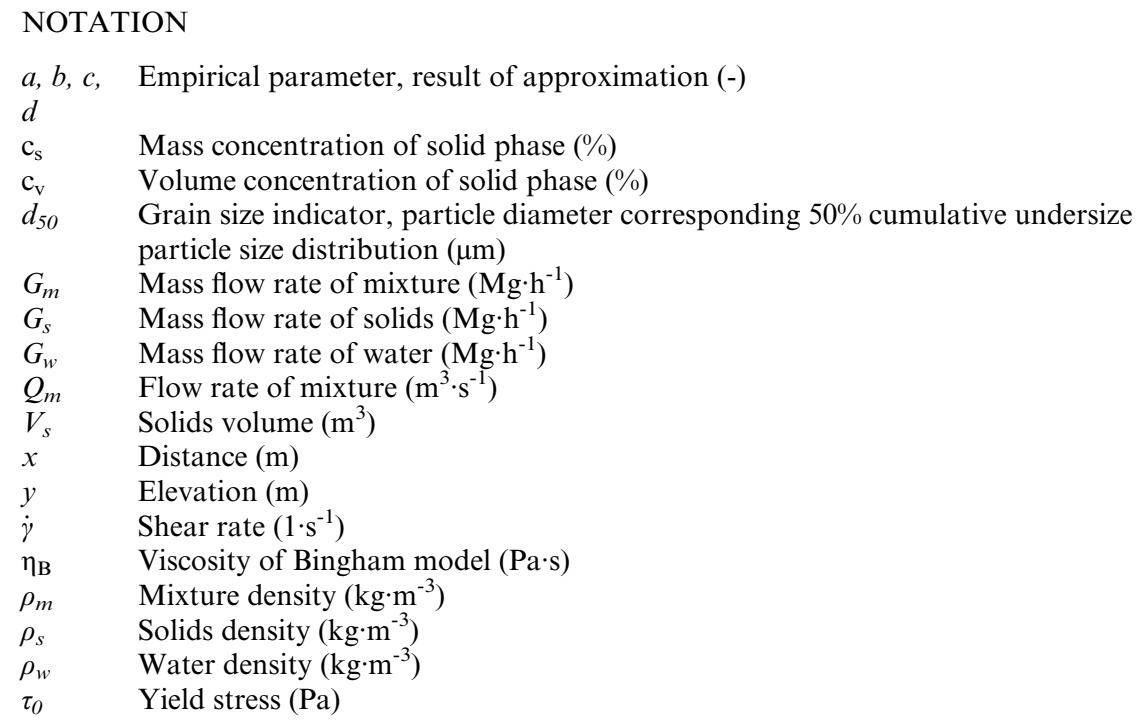

\section{CONCLUSIONS}

- The research confirms the existence of a Mature Fine Tailings deposit, completely deprived of sand fraction in the central part of Tailings Storage facility Żelazny Most

- The presented research results confirm the possibility of obtaining fine tailings thickened in the process of natural sedimentation from the central part of Tailings Storage facility Żelazny Most,

- The fine tailings can be used as a liquefaction additive, reducing the flow resistance to underground cemented backfill,

- The use of fine tailings obtained by the dredging method eliminates the need to use hydrocyclones to fractionate tailings stream from Ore Enrichment Plants,

- Rheological tests of samples taken during experiments have shown that the tested mixture is a non-Newtonian liquid,

- Bingham's rheological model satisfactorily describes the flow of the tested substance. It is possible to precisely describe the yield stress and viscosity of the Bingham model as a function of solid phase concentration for the tested density range,

- The obtained method of dredging fine-grained tailings naturally thickened can be considered to be the material for lithification,

- The experiments carried out on depositing of Mature Fine Tailings dredging method indicate that the slope of deposited material oscillates within $1 \%$,

- Mature Fine Tailings obtained by dredging method can be considered the material for backfill process.

\section{BIBLIOGRAPHY}

[1] Bochenek, D., Dzik, M., Górksa, A., Kiełczykowska, A., Kulasza, A., Nowakowska, B., Pawłowska, T., Rudnicka, M., Sulik, J., Szondelmejer, K., Wojciechowska, M., and Wrzosek, A. 2018. Environment 2018. Spatial and Environmental Surveys Department.

[2] Barnes et al. 2014 - Barnes, H., Hutton, J. and Walters K. An Introduction to Rheology, vol. 43, no. 1. Elsevier Science Publishers B.V. 
[3] Bartlett et al. 2013 - Bartlett, C. S., Burgess, H., Damjanović, B., Gowans, M. R. and Lattanzi, R. C. 2013. Technical Report on the copper-silver production operations of KGHM Polska Miedź S.A. in the Legnica-Glogów Copper Belt area of southwestern Poland, vol. 53, no. 9.

[4] Beier, N. and Sego, D. 2008. The Oil Sands Tailings Research Facility. Geotechnical News, no. June.

[5] Czaban et al. 2017 - Czaban, S., Gruszczyński, M., Pratkowiecki, R. and Skrzypczak Z. The measuring field system of fine tailings flow during dredging vessel," 18th International Freight Pipeline Society Symposium. Czech Association of Scientific and Technical Societies

[6] GeoPixel 2017. Wykonaliśmy nalot fotogrametryczny nad zbiornikiem unieszkodliwiania odpadów wydobywczych Żelazny Most - GeoPixel UAV dla geodezji. [Online] http://www.geopixel.pl/wykona lismy-nalot-fotogrametryczny-nad-zbiornikiem-unieszkodliwiania-odpadow-wydobywczychzelazny-most/. [Accessed: 20-Jul-2018].

[7] Gruszczyński et al. 2019- Gruszczyński, M.,. Błotnicki, J., Czaban, S. and Tymiński T. The effect of solid components on the rheological properties of copper ore tailings. International Conference of Transport and Sedimentation of Solid Particles. vol. TS 19, no. September, pp. 269-276.

[8] Gruszczyński, M. 2019. The assessment of the impact of the rheological parameters of fine-grained copper ore flotation tailings on friction head losses in pressure pipes. Wrocław University of Environmental and Life Sciences.

[9] Kotarska, I. 2012. Odpady wydobywcze z górnictwa miedzi w Polsce - bilans, stan zagospodarowania i aspekty środowiskowe, Cuprum, vol. 65, no. 4, pp. 45-64.

[10] Łuszczkiewicz, A. 2000. Koncepcje wykorzystania odpadów flotacyjnych z przeróbki rud miedzi w regionie Legnicko-Głogowskim," Inżynieria Mineralna. no. 1, pp. 25-36.

[11] M. H. Gorakhki and C. A. Bareither. 2017. Sustainable Reuse of Mine Tailings and Waste Rock as Water-Balance Covers. Minerals, vol. 7, no. 7, p. 128.

[12] N. Dhadli et al.2012. Technical Guide for Fluid Fine Tailings Management. Oil Sands Tailings Consort. Canada's Oil Sands Innovation Alliance, pp. 3-3 to 3-4,3-9,4-7.

[13] Pierzyna, P. and Popczyk, M. 2014. Odzysk odpadu energetycznego z metody mokrego odsiarczania spalin do likwidacji zbędnych wyrobisk górniczych. POLITYKA Energetyczna-ENERGY POLICY $J$., pp. 341-354.

[14] Plewa et al. 2008 - Plewa, F., Strozik, G. and Mysłek Z. Zastosowanie odpadów energetycznych do zestalania rumowiska skalnego Wprowadzenie. Polityka Energetyczna, pp. 351-360.

[15] Plewa et al. 2009 - Plewa, F., Strozik, G. and Piontek P. Zastosowanie ubocznych produktów spalania z kotłów fluidalnych energetyki zawodowej w podsadzce hydraulicznej Wprowadzenie. Polityka Energetyczna., vol. 12, no. 2/2, pp. 485-495.

[16] Plewa, F. 2006. - Plewa, F., Strozik, G. and Jendruś, R. Możliwośc zagospodarowania odpadów drobnofrakcyjnych $\mathrm{z}$ energetyki $\mathrm{w}$ procesie doszczelniania gruzowiska zawałowego $\mathrm{w}$ warunkach kopalni. Polityka Energetyczna. pp. 457-466.

[17] Popczyk, M. 2014. Możliwości zastosowania do podsadzki hydraulicznej mieszaniny piasku z żużlem energetycznym. Polityka Energetyczna - ENERGY POLICY J., pp. 405-416.

[18] Ratajczyk K. 2015. Spoiwo mineralne oparte na przetworzonych termicznie odpadach flotayjnych powstających w KGHM Polska Miedź S.A.," Prace Instytutu Ceramiki i Materiałów Budowlanych, vol. 21 , no. 18 , pp. 7-21.

[19] Speczik et al. 2003 - Speczik, S., Bachowski, A., Mizera, A. and Grotowski A. Stan aktualny i perspektywy gospodarki odpadami stałymi w KGHM Polska Miedź S.A. WARSZTATY 2003 z cyklu ,Zagrożenia Nat. w górnictwie”, pp. 155-177.

[20] Świdziński et al. 2015 - Świdziński, W., Tschuschke, W., Świerczyński, W. and Wolski W. Obiekt Unieszkodliwiania Odpadów Wydobywczych „Żelazny Most” - olbrzymie wyzwanie geotechniczne. Inżynieria Morska i Geotechniczna., vol. nr 3.

[21] Wang et al. 2014 - Wang, C., Harbottle, D., Liu, Q. and Xu, Z. Current State of Fine Mineral Tailings Treatment - A Critical Review on Theory and Practice. Mineral Engineering, vol. 58, no. c, pp. $113-131$.

[22] Wells et al. 2011 - Wells, P., Revington, A. and Omotoso O. Mature fine tailings drying - technology update [In:] 14th International Seminar on Paste and Thickened Tailings, Perth. 2011 5-7 April. Australian Centre for Geomechanics, pp. 155-166. 